\title{
Analysis the Determinants of Stock Price: An Empirical Study of Indonesian Commercial Banks
}

\author{
Farida $^{1}$, Anissa Hakim Purwantini ${ }^{2}$, Desi Nurpitasari ${ }^{3}$ \\ \{anissa.hakim@ummgl.ac.id ${ }^{1}$ \} \\ Department of Accounting, Universitas Muhammadiyah Magelang, 56122, Indonesia ${ }^{1,2,3}$
}

\begin{abstract}
The stock price is the price of a share that occurs on the stock exchange at a particular time, determined by market participants based on the level of demand and supply. Erratic prices present challenges and opportunities to invest, especially during this pandemic era. Precise analysis of stock prices will provide opportunities for investors to get high returns. This study investigates the external factors that influence stock prices in the banking sector in Indonesia. The data analysis method used is the regression analysis and paired test method. This study's sample consisted of 37 commercial banks listed on the Indonesia Stock Exchange (IDX) from 2019-2020. The number of data observations using purposive sampling is 444 samples. The results reveal that inflation, economic growth, and the money supply have no impact on stock prices. Meanwhile, the rupiah exchange rate and interest rates have a positive impact on stock prices. The results also find that there are differences in stock prices before and during the Covid-19 pandemic. Exciting research results and contributions are also discussed.
\end{abstract}

Keywords: Stock price; commercial bank; covid-19 pandemic; macroeconomic

\section{Introduction}

Nowadays, coronavirus created enormous volatility in the global stock market, leading to a downward trend in the overall stock position. This was caused by the high panic experienced by the community due to the Covid-19 pandemic outbreak. The panic caused an adverse reaction to the stock market, which is very sensitive to people's expectations [1]. The Indonesian capital market experienced a drastic decline due to the Covid-19 pandemic. Prior to confirmation of the first COVID-19 in Indonesia, the Composite Stock Price Index (IHSG) was at the level of 6,244 (24 January 2020), weakened to 5,942 (20 February 2020) and was corrected again to the level of 5,361 (2 March 2020). When the WHO declared a pandemic on 12 March 2020, the IHSG fell 4.2 percent to 4,937 when Thursday's session opened. This level is the lowest in almost four years. On 13 March 2020, stock trading was halted for the first time since 2008 due to the Covid19 pandemic [2].

Prior research has investigated the Covid-19 pandemic and its effect on stock prices. Covid19 harms company performance in China [3]. In the stock market sector, stock return prediction posits by health news [4], the effect of covid-19 outbreaks on stock markets in various countries [5]; the stock market in different sectors [6] and the difference in Composite Stock Prices Index before and during covid [2]; [7]; [8];[9]. External factors (i.e., interest rates, money supply, inflation, exchange rates, and economic conditions) also play an essential role in determining stock prices. Changes that occur in external factors will be a fast response by the market, creates 
a high potential risk in investment. However, little research focuses on investigating the influence of external factors on stock prices, especially in the covid-19 pandemic era. Pandemic distorts the positive relationship between inflation and stock market returns [10].

This study focuses on investigating external factors that affect stock prices on Indonesian commercial banks. Banking is one of the key industrial sectors contributing to the Composite Stock Price Index (IHSG) value in the Indonesia Stock Exchange. The existence of banking becomes the driving force for economic activity. The presence of banking as the intermediary financial institution, especially during a covid-19 pandemic, is crucial. Since the coronavirus outbreak, banks have limited the amount of credit distribution but still have to pay remuneration to savings customers. Therefore, banks have to minimize defaults by creditors. On the other hand, government policies, i.e., social distancing and PSBB (large-scale social restrictions), have made most business actors unable to carry out their business activities. This increases the potential for default on loans, which affects the decline in banking performance. The research refers to the prior study [11], which examines the inflation variable, the rupiah exchange rate, interest rates, and economic growth. This research adds the money supply variable. The money supply is a macroeconomic factor that can affect the ups and downs of stock prices. Besides, this study analyzes the differences in stock prices before and during the Covid-19 pandemic. This study uses a sample of commercial banks listed on the Indonesia Stock Exchange for the period 2019-2020 with monthly data, namely before Covid-19 from July to December 2019 and during the Covid-19 pandemic from January to July 2020.

\section{Method}

This study uses a quantitative method approach using secondary data. The population in this study are commercial banks listed on the Indonesia Stock Exchange from 2019 to 2020. This study used a purposive sampling technique with several criteria, as follows: (a) commercial banks listed on the IDX during the 2019-2020 period and not delisted; and (b) commercial banks that include monthly data on closing share prices for July-December 2019 to January-June 2020. Table 1 summarizes the measurement of the variables in this study, referring to previous research [11].

Table 1. Variables Measurement

\begin{tabular}{lc}
\hline \multicolumn{1}{c}{ Variables } & Measurement \\
\hline $\begin{array}{l}\text { Stock price } \\
\text { Inflation }\end{array}$ & $\begin{array}{c}\text { Monthly closing price during the } 2019-2020 \text { period } \\
\text { Inflation }=\frac{I H K-I H K_{-1}}{I H K_{-1}} X 100\end{array}$ \\
$\begin{array}{l}\text { Rupiah exchange rate } \\
\text { Interest rate }\end{array}$ & middle value $=\frac{\text { selling price }+ \text { purchase price }}{2}$ \\
Economic growth & The monthly closing price for SBI interest rates for the 2019-2020 \\
observation period & Gross Domestic Product $(G D P)-G D P_{t}-1$ \\
Money supply & Economic Growth $=\frac{\text { Goney Supply }- \text { Money Supply }_{t}-1}{\text { Money Supply }}$ \\
\hline
\end{tabular}

The total sample used was 37 banks with 444 observations. We use multiple linear regression to test the independent variable's effect (i.e., inflation (INF), the rupiah exchange rate 
(RER), interest rates (IR), economic growth (EG), and the money supply (MS)) on the dependent variable, stock prices (SP). We also examine differences in stock prices before and during the COVID-19 pandemic using the paired sample test with 222 observations. The regression equation model for stock prices is written as:

$$
S P=\alpha+\beta_{1} I N F+\beta_{2} R E R+\beta_{3} I R+\beta_{4} E G+\beta_{5} M S+\varepsilon
$$

\section{Results and Discussion}

The results of the classical assumption test suggest that the data do not experience multicollinearity, homoscedastic, autocorrelation, and normal distribution. Thus, the regression model formed is suitable to be used to solve this research problem.

\subsection{Multiple regression analysis}

The F test is used to assess the feasibility of this research model. The test results show that the calculated F-count is 4,382 with a probability level of $0.000<0.05$. The F-table value is 2.27. These results indicate that F-count (4.382) > F-table (2.27), then Ha is accepted and Ho is rejected. This means that the model used is good (fit).

The hypothesis testing results are presented in Table 2 (linear regression test) and Table 3 (paired sample test) as follows.

Table 2. Regression test results

\begin{tabular}{llrl}
\hline \multicolumn{1}{c}{ Hypothesis } & t-value & Sig. & \multicolumn{1}{c}{ Result } \\
\hline Inflation $\rightarrow$ SP $(-)$ & -0.909 & 0.364 & H1 not supported \\
Rupiah exchange rate $\rightarrow$ SP $(+)$ & 2.046 & 0.042 & H2 supported \\
Interest rate $\rightarrow$ SP $(-)$ & 2.910 & 0.004 & H3 not supported \\
Economic growth $\rightarrow$ SP (+) & -0.637 & 0.525 & H4 not supported \\
The money supply $\rightarrow(+)$ & 0.256 & 0.799 & H5 not supported \\
\hline
\end{tabular}

Table 3. Paired Samples Test

\begin{tabular}{llccc}
\hline & & t-value & Sig. & Result \\
\hline Pair 1 & Before Covid-During Covid & 5.365 & 0.000 & H6 supported \\
\hline
\end{tabular}

The regression results in Table 2 show that only one hypothesis is supported (H2). Inflation variable with t count -0.909 and a significance level of $0.364>0.05$, the hypothesis is not accepted. This shows that inflation has no impact on stock prices. The rupiah exchange rate shows a t-count of 2.046 with a significance of $0.042<0.05$, so the hypothesis is accepted. This means that the rupiah exchange rate has a positive effect on stock prices. The interest rate variable obtained t count 2.910 with a significance of $0.004<0.05$, and it is concluded that the hypothesis is not accepted. However, these results indicate that the interest rate has a positive effect on stock prices. Moreover, the economic growth variable with t count -0.637 with a significance of $0.525>0.05$, the hypothesis is not accepted. This means that economic growth has no impact on stock prices. The variable money supply with a t-count of 0.256 and a significance level of $0.799>0.05$ concludes that the hypothesis is not accepted. Thus the money 
supply has no impact on share prices. The paired sample test results in Table 3 show a significant level of $0.00<0.05$; that is, there is a difference in stock prices before the Covid-19 pandemic and during the Covid-19 pandemic.

\subsection{Discussion}

\subsubsection{The effect of inflation on stock prices}

The results showed that inflation has no negative impact on stock prices. High or low inflation rates have no effect on stock prices in the banking sector. During the Covid-19 pandemic, inflation that occurred in May 2020 was meager, at $0.07 \%$ month to month. This low level of inflation is caused by weakening people's purchasing power due to the coronavirus outbreak's impact. The WFH (work from home) policy resulted in a decline in the majority of the population's income, which led to lower inflation in the food and beverage sector [12]. This study is consistent with previous research [11], which proved that inflation had no impact on the IHSG.

\subsubsection{The effect of rupiah exchange rate on stock prices}

The test results show that the rupiah exchange rate has a positive impact on stock prices. It means that if the exchange rate increases, the stock price will increase, and vice versa if the exchange rate decreases, the stock price will decrease. If the rupiah exchange rate strengthens, economic conditions increase, and the capital market also increases rising stock prices. The rupiah exchange rate will have an impact on the stock returns that investors get. When the rupiah strengthens, investors will invest because the resulting return is high. During this pandemic period, the rupiah exchange rate weakened so that the resulting return decreased, which resulted in changes in stock prices. This study's result is consistent with prior studies [13], which indicate that the rupiah exchange rate positively affects company stock prices food and beverage sector in the covid-19 pandemic era.

\subsubsection{The effect of interest rate on stock prices}

The results showed that the interest rate, as measured by the BI Rate, positively impacts stock prices. This result is different from the hypothesis proposed; the interest rate has a negative impact on stock prices. This research indicates an increase in stock prices when interest rates rise, and when interest rates fall, share prices also decline. Interest rates are also determined by the existence of a supply or demand for money. During this pandemic, BI issued a policy of lowering interest rates to maintain economic stability. However, the impact of the Covid-19 pandemic has resulted in individuals being more inclined to invest in savings and deposits even though the returns have decreased compared to investing in the stock capital market. Expectations for banking performance are still low despite falling lending rates. The decline in credit interest rates did not increase credit demand in line with sluggish economic growth [14].

\subsubsection{The effect of economic growth on stock prices}

The results of this study indicate that economic growth has no positive impact on stock prices. This suggests that an increase or decrease in economic growth does not affect stock prices. GDP (Gross Domestic Product) growth is a reflection of economic growth. Improved 
economic growth will increase people's purchasing power. Economic growth also impacts companies with an increase in profits from increased sales [15]. Investors will make investment decisions based on the company's rate of return, namely stock dividends. When economic growth is profitable, dividends tend to increase. However, during the Covid-19 pandemic, economic growth declined, and people tended to use their money/funds to consume goods and services. Therefore, investment in the stock market is less attractive. This result indicates that economic growth has no significant effect on stock prices [15].

\subsubsection{The effect of money supply on stock prices}

This study shows that the money supply has no positive impact on stock prices. This indicates that an increase or decrease in the money supply does not affect stock prices. The money supply does not affect the stock price because the inflation rate's pressure is still in the low category. The outbreak of the coronavirus has caused a decline in the economic sector in all fields. The money supply has also experienced slowing growth. Some of the factors that triggered the slowdown were the decline in savings and foreign exchange and decreased productive credit distribution due to the impact of the covid-19 pandemic. This research is consistent with a prior study [16], which states that the money supply does not affect the IHSG.

\subsubsection{The difference of stock prices before and during covid-19 pandemic}

Different test results show that there are differences in stock prices before and during the Covid-19 pandemic. This indicates that there has been a change in stock prices from 2019 to 2020. The data obtained reveal that the stock price before the pandemic had a higher price than the pandemic's stock price. This means that share prices during the Covid-19 pandemic experienced a significant decline in stock prices due to adverse market sentiment [17]. The decline in the stock price of the IHSG had an impact on banking stock prices, which experienced a decrease in share prices. At the close of the second trading session on 6 March, 2020, several banking issuers experienced a varying decline in share prices. BBRI shares closed down 3.37 percent to Rp4,010, BBCA contracted 3.65 percent to Rp31,000. Furthermore, BMRI shares have decreased by 4.61 percent to the price of Rp7,250. Meanwhile, BBNI fell 6.23 percent to Rp6,400, while BBTN fell 3.49 percent to Rp1,660 [16].

\section{Conclusion}

This study examines external factors that influence stock prices in the commercial banking sector in Indonesia. This study indicates that external factors in macroeconomics, i.e., inflation, economic growth, and the money supply, have no impact on stock prices. Meanwhile, the rupiah exchange rate and interest rates have a positive impact on banking stock prices. The pair sample t-test shows differences in stock prices before and during the Covid 19 pandemic. This study is limited to a short observation period of one year consisting of six months before the pandemic and six months during the pandemic. Future research may focus on daily data for more specific results. Besides, the sample of this study is conventional banking. Furthermore, the future study can compare it with sharia-based banking. 


\section{References}

[1] D. Tashanova, A. Sekerbay, D. Chen, Y. Luo, S. Zhao, and Q. Zhang, "Investment Opportunities and Strategies in an Era of Coronavirus Pandemic," 2020. doi: 10.2139/ssrn.3567445.

[2] Haryanto, "Dampak Covid-19 terhadap Pergerakan Nilai Tukar Rupiah dan Indeks Harga Saham Gabungan (IHSG)," Jurnal Perencanaa Pembangangunan: The Indonesian Journal of Development Planning, vol. 4, no. 2, pp. 151-165, 2020, doi: 10.36574/jpp.v4i2.114.

[3] H. Shen, M. Fu, H. Pan, Z. Yu, and Y. Chen, "The Impact of the COVID-19 Pandemic on Firm Performance," Emerg. Mark. Finance. Trade, vol. 56, no. 10, pp. 2213-2230, 2020, doi: 10.1080/1540496X.2020.1785863.

[4] A. A. Salisu and X. V. Vo, "Predicting stock returns in the presence of COVID-19 pandemic: The role of health news," Int. Rev. Financ. Anal., vol. 71, no. June, p. 101546, 2020, doi: 10.1016/j.irfa.2020.101546.

[5] O. Erdem, "Freedom and stock market performance during Covid-19 outbreak," Finance. Res. Lett., vol. 36, no. June, pp. 1-6, 2020, doi: 10.1016/j.frl.2020.101671.

[6] P. He, Y. Sun, Y. Zhang, and T. Li, "COVID -19's Impact on Stock Prices Across Different Sectors-An Event Study Based on the Chinese Stock Market," Emerg. Mark. Finance. Trade, vol. 56, no. 10, pp. 2198-2212, 2020, doi: 10.1080/1540496X.2020.1785865.

[7] M. R. Hutauruk, "The Impact Before and After Pandemic Covid-19 Phenomenon On The Idx Composite". Advanced Journal of Banking Investment and Taxation, Vol. 1, no. 1, pp. 1-11, 2020.

[8] M. H. Rifa'i, Junaidi, and A. F. K. Sari, "Pengaruh Peristiwa Pandemi Covid-19 Terhadap Indeks Harga Saham Gabungan," E-Jra, vol. 09, no. 02, pp. 47-57, 2020.

[9] D. Junaedi and F. Salistia, "Dampak Pandemi Covid-19 Terhadap Pasar Modal Di Indonesia:," AlKharaj Jurnal Ekonomi Keuangan Bisnis Syariah, vol. 2, no. 2, pp. 109-138, 2020, doi: 10.47467/alkharaj.v2i4.112.

[10] G. Jelilov, P. T. Iorember, O. Usman, and P. M. Yua, "Testing the nexus between stock market returns and inflation in Nigeria: Does the effect of COVID-19 pandemic matter?," J. Public Aff., vol. 20, no. 4, pp. 1-9, 2020, doi: 10.1002/pa.2289.

[11] M. Indriati, V. Juliana Dillak, and D. Zulistina, "Pengaruh Inflasi, Nilai Tukar Rupiah, Tingkat Suku Bunga Dan Pertumbuhan Ekonomi Terhadap Indeks Harga Saham Gabungan Di Bursa Efek Indonesia Periode 2009-2018," Stat. F. Theor, vol. 53, no. 9, pp. 1689-1699, 2019.

[12] Feni Freycinetia Fitriani, "Inflasi Mei 2020 0,07 Persen, Daya Beli Lemah Akibat Covid-19," 2 Juni, 2020. https://ekonomi.bisnis.com/read/20200602/9/1247591/inflasi-mei-2020-007-persen-dayabeli-lemah-akibat-covid-19-

[13] D. Kartikaningsih, "Pengaruh Nilai Tukar Terhadap Harga Saham Perusahaan Sektor Food and Beverage Di Masa Pandemi Covid-19," BISMA J. Bisnis dan Manaj., vol. 14, no. 2, p. 133, 2020, doi: 10.19184/bisma.v14i2.17862.

[14] N. P. E. Wiratmini, "Pengamat: Suku Bunga Turun, Kredit Berpotensi Lesu Hingga Akhir Tahun," 9 April, 2020. https://finansial.bisnis.com/read/20200409/90/1225076/pengamat-suku-bunga-turunkredit-berpotensi-lesu-hingga-akhir-tahun.

[15] A. P. Sari, "Pengaruh Jumlah Uang Beredar dan Pertumbuhan Ekonomi Terhadap Kinerja Reksadana Saham," J-MAS (Jurnal Manaj. dan Sains), vol. 4, no. 2, p. 362, 2019, doi: 10.33087/jmas.v4i2.120.

[16] F. Wibowo, R. Arifati, and K. Raharjo, "Analisis Pengaruh Tingkat Inflasi, Suku Bunga Sbi, Nilai Tukar Us Dollar Pada Rupiah, Jumlah Uang Beredar, Indeks Dow Jones, Indeks Nikkei 225, Dan Indeks Hangseng Terhadap Pergerakan Indeks Harga Saham Gabungan (IHSG) Periode Tahun 2010-2014," J. Account., vol. 2, no. 2 (Maret), pp. 1689-1699, 2016.

[17] H. T. Putri, "Covid 19 dan harga saham perbankan di Indonesia," Eksis Jurnal Ilmu Ekonomi dan Bisnis, vol. 11, no. 1, pp. 6-9, 2020, doi: 10.33087/eksis.v11i1.178. 